\title{
Morphological, Physiological, and Biochemical Responses of Zinnia to Drought Stress
}

\author{
Stefania Toscano (D) and Daniela Romano *(D) \\ Department of Agriculture, Food and Environment (Di3A), Università Degli Studi di Catania, Via Valdisavoia 5, \\ 95123 Catania, Italy; stefania.toscano@unict.it \\ * Correspondence: dromano@unict.it
}

check for updates

Citation: Toscano, S.; Romano, D. Morphological, Physiological, and Biochemical Responses of Zinnia to Drought Stress. Horticulturae 2021, 7, 362. https://doi.org/10.3390/ horticulturae7100362

Academic Editor: Othmane Merah

Received: 8 September 2021

Accepted: 30 September 2021

Published: 4 October 2021

Publisher's Note: MDPI stays neutral with regard to jurisdictional claims in published maps and institutional affiliations.

Copyright: (c) 2021 by the authors. Licensee MDPI, Basel, Switzerland. This article is an open access article distributed under the terms and conditions of the Creative Commons Attribution (CC BY) license (https:// creativecommons.org/licenses/by/ $4.0 /)$.

\begin{abstract}
Bedding plants in the nursery phase are often subject to drought stress because of the small volume of the containers and the hydraulic conductivity of organic substrates used. To analyse the morphological, physiological, and enzymatic responses of zinnia (Zinnia elegans L.) plants at different irrigation levels, four treatments were performed: irrigated at $100 \%$ (100\% field capacity, FC); light deficit irrigation (75\% FC), medium deficit irrigation ( $50 \% \mathrm{FC})$, and severe deficit irrigation (25\% FC). The growth of zinnia was significantly influenced by drought stress treatments. Different morphological parameters (dry biomass, leaf number, root to shoot ratio (R/S)) were modified only in the more severe drought stress treatment (25\% FC). The stomata density increased in $50 \%$ FC and $25 \%$ FC, while the stomata size was reduced in $25 \%$ FC. The net photosynthesis, stomatal conductance, and transpiration were reduced in 50\% FC and $25 \%$ FC. The relative water content (RWC) was reduced in $25 \%$ FC. Severe drought stress ( $25 \%$ FC) increased proline content up to seven-fold. Catalase (CAT), peroxidase (GPX), and superoxide dismutase (SOD) activity significantly increased in 50\% FC and 25\% FC. Principal component analysis (PCA) showed that the morphological and physiological parameters were mostly associated with the $100 \% \mathrm{FC}$ and $75 \% \mathrm{FC}$ treatments of the biplot, whereas the stomata density, R/S ratio, and antioxidant enzymes (GPX, CAT) were associated with 50\% FC, and proline and DPPH were associated with $25 \%$ FC, respectively.
\end{abstract}

Keywords: Zinnia elegans L.; bedding plants; deficit irrigation; stomata characteristics; gas exchange; proline; enzyme activity

\section{Introduction}

Bedding plants play a relevant role in public green areas and private gardens. These plants can suffer from drought stress because they are not always properly watered, especially when grown in pots or show small root systems [1]. Bedding plants are in fact at greater risk of undergoing drought stress during the nursery phase because they are cultivated in small pots that can limit root growth, making the plants subject to greater levels of drought stress. Furthermore, the hydraulic conductivity of the substrates, which are often organic, used in the production of bedding plants decreases rapidly with small changes in the substrate water content [2], making the extraction of water very difficult for plants when the water content in the substrate is low. However, limited research exists regarding the physiological mechanisms that allow bedding plants to tolerate drought stress.

Drought stress results in damage to the plant's physiological and biochemical processes and represents one of the most relevant environmental factors that impair plant growth and performance [3]. Plants may exhibit numerous drought stress response mechanisms at the morphological and physiological levels [4,5]. At the level of the whole plant, some species increase their root biomass to enhance water uptake [6] and hence maintain the water state of the plant and ensure photosynthesis in drought conditions. In the nursery stage of bedding plant cultivation, this acclimatization response may not be possible because both root growth and available water are limited by the small pots. 
Exposure to drought stress causes morphological changes in shoots; the plants produce smaller leaves and drop the older leaves to reduce transpiration and hence water loss [7]. The reduction in leaf area, if it can help maintain a favourable water status of the plant, reduces plant photosynthesis and plant carbon gain. Photosynthesis, which is essential for plant growth, markedly declines in plants in drought conditions because this process is highly sensitive to drought stress [8]. Although several studies have analysed the influence of drought conditions in the modification of the photosynthesis in bedding plants [9], there is limited research-based information linking the morphological, physiological, and biochemical acclimatization to drought in bedding plants. This information can be important for deepening the knowledge on the physiological responses of plants to drought, individuating guidelines to mitigate drought stress, and for selecting and developing suitable species to resist water shortages [10].

In drought conditions, water loss reduction at the leaf level is determined by transiently lowering stomatal conductance (gs) [11]; this can help maintain the level of foliar photosynthesis in drought conditions, albeit at a lower rate, for a longer time. In plants exposed to drought stress, a good correlation between gs and leaf water potential was observed [12].

Osmotic adaptation on a cellular scale is a drought acclimatization response to the concentration of compatible solutes within cells [13]. This reduces leaf water and maintains the potential gradient necessary for root water uptake from the substrate and allows the maintenance of a positive turgor potential in drought conditions [14]. Although light-harvesting mechanisms, including photosystems, are generally tolerant to drought stress, severe stress levels can impair photosystem II [15]. Drought stress causes lipid peroxidation and causes irreversible damage to the structural and functional integrity of the membrane [16]. For this reason, the accumulation of malondialdehyde (MDA) in the cell and the stability of the cell membrane are widely used as indicators of plant tolerance to drought stress [17].

Plants show various physiological and biochemical responses to drought stress. The accumulation of osmotic compounds, such as proline, is one of the most common plant responses to drought stress [18]. Proline is a compatible solute involved in cellular osmotic regulation and the protection of cellular components during dehydration [19].

Activation of the antioxidant defence and osmoprotection systems are two main drought resistance mechanisms in plants [20,21]. The overproduction of reactive oxygen species (ROS) under stress conditions is a typical tolerance response [22]. ROS assure a key role in the process of acclimatization to various abiotic stresses [23]. Antioxidant mechanisms, both enzymatic and non-enzymatic, are known to be involved in plant protection against ROS. A physiological mechanism for mitigating the negative effects of ROS on plant cells are antioxidant enzymes; among these are catalase (CAT), superoxide dismutase (SOD), and ascorbate peroxidase (APX), which determine the protection of plant cells against oxidative damage [24]. Studies have shown antioxidant enzymatic activity is positively associated with plant stress tolerance, which has been found in various field crops, such as pea [25], maize [26], and wheat [27].

Proline also works as a free radical scavenger and suppresses free radical-mediated damage during drought stress. Several studies have demonstrated that, during drought stress conditions, proline content increases, and proline buildup is associated with more efficient drought tolerance in tall fescue and other plants [19].

Among the ornamental summer flowering plants, zinnia (Zinnia elegans L.) is rightly appreciated for its spectacular display of colourful flowers [28]. It belongs to the Compositae family (Asteraceae) and it is native to Central America and Mexico. Zinnia flowers have a long vase life and present uniform and bright colours and sturdy stems [29]. It is one of the suitable bedding and cut flower plants grown during the summer season in hot climates [30].

The application of deficient irrigation strategies to floriculture can make a significant contribution to the conservation of irrigation water. In the near future, the warming climate 
will enhance the frequency and severity of drought [31]. Therefore, in a changing climate, studying the main physiological limits to productivity in drought conditions will be crucial for enhancing yield stability.

Because the increased drought frequency strongly negatively affects plant growth and development [32], analyzing the effects of water deficit on plants is relevant to hypothesise the influence of future climate changes on the growth of a particular plant species [33]. Among bedding plants, studying the response to drought stress in various species and/or cultivars is strategic to individuate genotypes able to improve landscape performance and expand the use of these plants in drought areas [34].

The aim of this research was to determine the morphological, physiological, and enzymatic responses of zinnia plants at different irrigation levels and to evaluate the response to different intensities of drought and hence the possibility to reduce the water quantity used in the nursery phase.

\section{Materials and Methods}

\subsection{Experimental Conditions, Plant Material, and Irrigation Treatments}

The trial was realised in a nursery near Catania, Italy $\left(37^{\circ} 41^{\prime} \mathrm{N} 15^{\circ} 11^{\prime} \mathrm{E} 89 \mathrm{~m}\right.$ a.s.l.) in April 2021 on zinnia (Zinnia elegans L.). Seeds of zinnia 'Limette', (Fratelli Ingegnoli, Milan, Italy) were sown in cellular trays on the substrate Brill ${ }^{\circledR}$ Semina Bio (Geotec, Bolzano, Italy). At the fourth leaf stage, the seedlings were transplanted into $10 \mathrm{~cm} \varnothing$ pots (one plant per pot), filled with peat and soil $(2 / 1, v / v)$, and fertilised with $2 \mathrm{~g} \mathrm{~L}^{-1}$ of Osmocote Plus (14/13/13, N,P,K + microelements).

Plants were grouped into three repetitions of nine plants per treatment and irrigated every day for 30 days. Four treatments were performed: irrigated at 100\% (100\% field capacity, FC), light deficit irrigation (75\% FC), irrigated at 75\% from the $100 \%$ FC treatment, medium deficit irrigation ( $50 \% \mathrm{FC}$ ), irrigated at $50 \%$ from the $100 \%$ FC treatment and severe deficit irrigation $(25 \% \mathrm{FC})$, and irrigated at $25 \%$ from the $100 \%$ FC treatment. Water loss was determined following the methodology of Toscano et al. [35] through the gravimetric method; during the experimental period, the differences in weights (weight after irrigation, weight when drainage stopped, and weight before reirrigating) were calculated.

The treatments started when the plants showed four leaves and ended after 30 days when approximately $50 \%$ of plants showed the beginning of inflorescence emergence.

To determine the maximum water-holding capacity of the substrate, pots were mixed and submerged in water to $50 \%$ of their height, and the substrate was left to imbibe overnight. To avoid water evaporation, aluminium foil was placed on the upper surfaces of the containers. The next day, the containers were removed from the water bath and left to drain until reaching a constant weight. The weight of each container was then determined and considered as the weight at volumetric water content. Then, the substrate was dried in a thermo-ventilated oven at $105{ }^{\circ} \mathrm{C}$ until reaching a constant weight to determine the dry weight and calculate the volumetric water content. The difference between the fresh and dry weight was calculated, and the volumetric water content was determined $(75 \%)$ and used as the substrate's container capacity [36].

The mean air temperature, relative humidity, and global radiation were determined on a data logger CR1000 (Campbell Scientific Ltd., Loughborough, UK) during the experimental periods. The minimum, maximum, and mean temperatures were 16.9, 54.6, and $26.2{ }^{\circ} \mathrm{C}$, respectively. The mean relative humidity $(\mathrm{RH})$ was $58.8 \%$.

\subsection{Biomass and Leaf Area}

After the experimental period ended, for six plants per treatment, the roots were separated from the substrate with tap water, and the aerial parts were divided into stems and leaves. Drying the weighed samples in a thermo-ventilated oven at $70{ }^{\circ} \mathrm{C}$ until reaching constant weight allowed the determination of dry biomass. The total leaf area was measured using a leaf area meter (Delta-T Devices Ltd., Cambridge, UK). 


\subsection{Stomata Characteristics}

Unfolded and mature leaves (4 leaves per treatment and for each repetition) were detached from the plants and used for stomata characteristics. A microscope (Nikon Eclipse E200, Japan) was utilised for determining the number and size of the stomata. On each slide, along a diagonal transect of the peel, four stomata for three leaves for each repetition were measured for pore lengths at $40 \times$. Stomatal size (S) was defined by guard cell length and width.

\subsection{Leaf Gas Exchange, Chlorophyll a Fluorescence, and RWC}

At the end of the trial, the gas exchange in six plants per treatment (two plants for each repetition and three leaves per plant) was measured with a $\mathrm{CO}_{2} / \mathrm{H}_{2} \mathrm{O}$ infrared gas analyser (LCi, ADC Bioscientific Ltd., Hoddesdon, UK). The reliefs were carried out in the morning (from 09:00 to 13:00). For each drought stress treatment, the net photosynthetic rate $\left(\mathrm{A}_{\mathrm{N}}\right)$, stomatal conductance $(\mathrm{gs})$, transpiration rate $(\mathrm{E})$, and water use efficiency (WUE) were determined.

The chlorophyll $a$ fluorescence $(\mathrm{Fv} / \mathrm{Fm})$ was recorded in the same leaves using a modulated chlorophyll fluorimeter OS1-FL (Opti-Sciences Corporation, Tyngsboro, MA, USA). The leaf was dark-adapted using cuvette clips for $15 \mathrm{~min}$ (Opti-Sciences Corporation, Tyngsboro, MA, USA). The chlorophyll $a$ fluorescence was reported as the Fv/Fm ratio, where $\mathrm{Fm}=$ the maximum fluorescence and $\mathrm{Fv}=$ the variable fluorescence.

The relative water content (RWC) was evaluated on fully opened leaves. For each replicate, 30 discs $10 \mathrm{~mm}$ in diameter were taken, and the fresh weights (FW) were determined. Then, the samples were immersed in distilled water for $24 \mathrm{~h}$ and re-weighed to measure the turgid weight (TW). Subsequently, the samples were dried at $75^{\circ} \mathrm{C}$ for $24 \mathrm{~h}$ to measure the dry weights (DW). The RWC was expressed according to the formula:

$$
\mathrm{RWC} \%=(\mathrm{FW}-\mathrm{DW} / \mathrm{TW}-\mathrm{DW}) * 100
$$

\subsection{Determination of Chl and Carotenoid Content}

After ending the experiment, chlorophyll $a(\mathrm{Chl} a)$, chlorophyll $b(\mathrm{Chl} b)$, total chlorophyll, and carotenoids were determined. For the extraction, $100 \mathrm{mg}$ of fresh material was extracted with $5 \mathrm{~mL}$ of $99 \%$ methanol and incubated in the dark for $24 \mathrm{~h}$ at $4{ }^{\circ} \mathrm{C}$. Quantification was performed by spectrophotometry (7315 Spectrophotometer, Jenway, Staffordshire, UK) at $665.2 \mathrm{~nm}, 652.4 \mathrm{~nm}$, and $470 \mathrm{~nm}$. The calculation of chlorophylls was performed following the formula reported by Lichtenthaler et al. [37]:

$$
\begin{gathered}
\text { Chl } a=16.75_{\mathrm{A} 665.2}-9.16_{\mathrm{A} 652.4} . \\
\text { Chl } b=34.09_{\mathrm{A} 652.4}-15.28_{\mathrm{A} 665.2} . \\
\text { Carotenoids }=\left(1000_{\mathrm{A} 470}-1.63 \mathrm{Chl} a-104.96 \mathrm{Chl} b\right) / 221 .
\end{gathered}
$$

\subsection{Estimation of Proline Content}

Proline content was determined according to Ahmad et al. [38] using L-proline as the standard. Leaf samples $(1 \mathrm{~g})$ were homogenised in $5 \mathrm{~mL}$ of $3 \%$ aqueous sulfosalicylic acid and centrifuged at 14,000 $\times \mathrm{g}$ for $15 \mathrm{~min}$ (Neya 10R, REMI, Mumbai, India). The homogenate $(2 \mathrm{~mL})$ was added at the same quantity of acetic acid and ninhydrin, mixed and incubated for $1 \mathrm{~h}$ at $100{ }^{\circ} \mathrm{C}$. Then, the reaction was stopped in an ice bath, and the supernatant was extracted with $4 \mathrm{~mL}$ of toluene. The absorbance of the extract was read at $525 \mathrm{~nm}$ (7315 Spectrophotometer, Jenway, Staffordshire, UK).

\subsection{Estimation of $M D A$ Content}

Malondialdehyde (MDA) content was determined according to Li et al. [39]. Leaf samples $(0.5 \mathrm{~g})$ were extracted in $1.5 \mathrm{~mL}$ of $5 \%$ trichloroacetic acid $(w / v)$. The homogenate was centrifuged at $5000 \times \mathrm{g}$ for $10 \mathrm{~min}$, and then the extract was diluted to $10 \mathrm{~mL}$. A quantity of $2 \mathrm{~mL}$ of the diluted extract was homogenised with the same quantity of $0.67 \%$ 
thiobarbituric acid. The mixture was incubated at $95^{\circ} \mathrm{C}$ for $30 \mathrm{~min}$ and then centrifuged at $5000 \times g$ for $10 \mathrm{~min}$. The MDA content was calculated using the following formula: $\mathrm{C}(\mu \mathrm{mol} / \mathrm{L})=6.45 \times\left(\mathrm{A}_{532}-\mathrm{A}_{600}\right)-0.56 \times \mathrm{A}_{450}$.

\subsection{Extraction and Assay of Antioxidant Enzymes}

Leaf samples $(0.5 \mathrm{~g})$ were extracted with $4 \mathrm{~mL}$ of extraction buffer $(50 \mathrm{mM}$ potassium phosphate, $1 \mathrm{mM}$ ethylenediaminetetraacetic acid [EDTA], 1\% polyvinylpyrrolidone [PVP], $1 \mathrm{mM}$ dithiothreitol [DTT], and $1 \mathrm{mM}$ phenylmethylsulfonyl [(PMSF), $\mathrm{pH}$ 7.8). The samples were centrifuged $\left(15,000 \times g\right.$ for $\left.30 \mathrm{~min}, 4^{\circ} \mathrm{C}\right)$, and the supernatant was used for the enzyme assay [40].

The catalase activity (CAT; EC 1.11.1.6) was evaluated according to Aguilera et al. [41] with modifications; $20 \mu \mathrm{L}$ of the extract was homogenised to $830 \mu \mathrm{L}$ potassium phosphate buffer ( $50 \mathrm{mM}, \mathrm{pH}$ ). The reaction started with the addition of $150 \mu \mathrm{L}$ of $\mathrm{H}_{2} \mathrm{O}_{2}$, and the decrease was monitored at $240 \mathrm{~nm}$ for $2 \mathrm{~min}$. The unit of CAT was expressed as units $\mathrm{mg}^{-1}$ protein.

The glutathione peroxidase activity (GPX) was determined according to Ruley et al. [42]. The same amount of extract and $17 \mathrm{mM} \mathrm{H}_{2} \mathrm{O}_{2}$ was homogenised with $2 \%$ guaiacol to obtain a final volume of $1 \mathrm{~mL}$. The increase in absorbance was monitored at $510 \mathrm{~nm}$ for $3 \mathrm{~min}$. The activity of GPX was defined as units $\mathrm{mg}^{-1}$ protein.

The superoxide dismutase activity (SOD; EC 1.15.1.1) was evaluated following Giannopolitis and Ries [43]. The SOD activity was read at $560 \mathrm{~nm}$; the unit of SOD was defined as the amount of enzyme required to cause $50 \%$ inhibition of the reduction of NBT. The unit of SOD was expressed as units $\mathrm{mg}^{-1}$ protein.

Using Bradford's method [44], the protein content was quantified.

All samples were read using a spectrophotometer (7315 Spectrophotometer, Jenway, Staffordshire, UK).

\subsection{2,2-Diphenyl-1-picrylhydrazyl (DPPH) Radical Scavenging Activity}

The scavenging activity against the DPPH radical was evaluated using DPPH. A quantity of $1 \mathrm{~g}$ of fresh weight was homogenised with $1.5 \mathrm{~mL}$ of $80 \%$ methanol, sonicated for $30 \mathrm{~min}$, and centrifuged for $10 \mathrm{~min}$ at $5{ }^{\circ} \mathrm{C}$ and $5000 \times \mathrm{g}$. Subsequently, $0.01 \mathrm{~mL}$ of the supernatant was homogenised with $1.4 \mathrm{~mL}$ of DPPH solution $(150 \mu \mathrm{M})$ and incubated for $30 \mathrm{~min}$ in the dark. Later, the samples were read at $517 \mathrm{~nm}$. The DPPH activity was expressed as Trolox equivalent antioxidant activity $\left(\mathrm{mg} \mathrm{TE}^{-1}\right)$.

\subsection{Statistical Analysis}

The trial was conducted as a randomised complete design with three replicates. The statistical analyses were conducted with CoStat version 6.311 (CoHort Sofware, Monterey, CA, USA); one-way ANOVA was adopted. The differences between the means were determined using Tukey's test $(p<0.05)$. The data presented in the figures are the means \pm standard error (SE) (Graphpad 7.0). The principal component loading plot and scores of PCA were performed using Minitab 16, LLC.

\section{Results}

\subsection{Evapotranspiration}

Figure 1 shows the trend of evapotranspiration $\left(\mathrm{L} \mathrm{day}^{-1}\right)$ in the $100 \%$ FC treatment during the experimental period. The amounts of water manually added to each pot were $1.88,1.41,0.92$ and $0.47 \mathrm{~L}$, respectively, for $100 \% \mathrm{FC}, 75 \% \mathrm{FC}, 50 \% \mathrm{FC}$ and $25 \% \mathrm{FC}$. The electrical conductivity of the water was $0.005 \mathrm{dS} \mathrm{m}^{-1}$. 


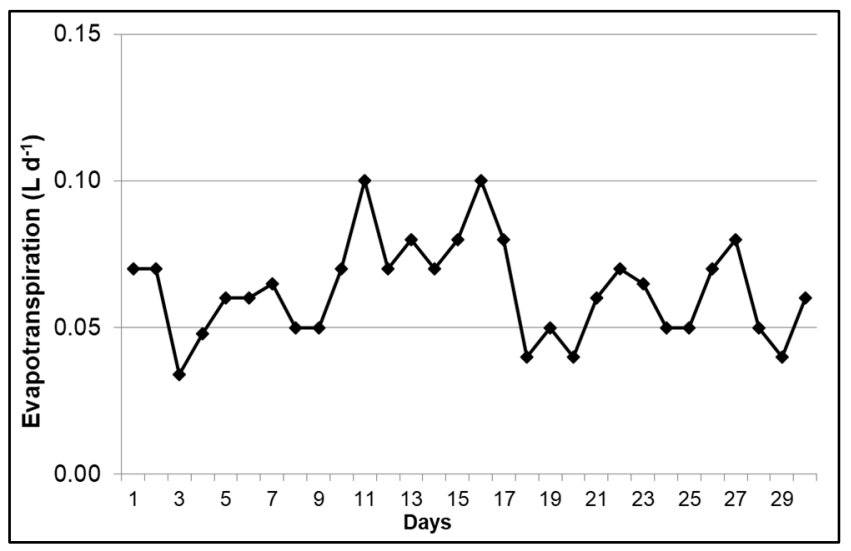

Figure 1. Evapotranspiration $\left(\mathrm{L} \mathrm{d}^{-1}\right)$ in zinnia $100 \%$ FC during the experimental period (30 days).

\subsection{Biomass and Leaf Area}

The growth of zinnia was significantly modified by drought stress treatments. Plant height was reduced because of the different irrigation regimes (Table 1). By increasing the level of drought stress from control to $25 \% \mathrm{FC}$, the height was reduced by $\sim 17 \%$ and $\sim 38 \%$, respectively, for 50\% FC and 25\% FC ( $p<0.001)$. No significant differences were observed in 75\% FC compared with unstressed plants (Table 1). A similar trend was observed for the stem diameter, with a reduction in more stressed treatments by $\sim 23$ and $\sim 37 \%$, respectively, for $50 \%$ FC and $25 \%$ FC $(p<0.001)$. Leaf number was significantly reduced under $25 \%$ FC (by 39\%) compared with the other treatments $(p<0.001)$ (Table 1$)$; the total leaf area showed a decrease from the moderate deficit irrigation with a reduction of $21 \%$ in $50 \%$ FC and by $50 \%$ in $25 \%$ FC. $(p<0.001)$. No significant differences were observed in $75 \%$ FC (Table 1).

Table 1. Effects of irrigation treatments on plant height $(\mathrm{cm})$, stem diameter $(\mathrm{mm})$, leaf number $(\mathrm{n}$.$) , total leaf area \left(\mathrm{cm}^{2}\right)$, leaf, stem, root fresh weight $\left(\mathrm{g} \mathrm{plant}^{-1}\right)$, total dry biomass $\left(\mathrm{g} \mathrm{plant}^{-1}\right)$, and root/shoot ratio (R/S) of potted zinnia plants at the end of the experimental period. Plants were irrigated every day. Four treatments were performed: irrigated at $100 \%$ ( $100 \%$ field capacity, FC); light deficit irrigation (75\% FC), irrigated at $75 \%$ from the $100 \%$ FC treatment; medium deficit irrigation ( $50 \% \mathrm{FC})$, irrigated at 50\% from the $100 \%$ FC treatment and severe deficit irrigation ( $25 \% \mathrm{FC})$, and irrigated at $25 \%$ from the $100 \%$ FC treatment.

\begin{tabular}{|c|c|c|c|c|c|c|c|c|c|}
\hline $\begin{array}{l}\text { Drought } \\
\text { Stress }\end{array}$ & $\begin{array}{l}\text { Plant } \\
\text { Height } \\
\text { (cm) }\end{array}$ & $\begin{array}{c}\text { Stem } \\
\text { Diameter } \\
(\mathrm{mm})\end{array}$ & $\begin{array}{c}\text { Leaf } \\
\text { Number } \\
\text { (n.) }\end{array}$ & $\begin{array}{c}\text { Total Leaf } \\
\text { Area } \\
\left(\mathrm{cm}^{2}\right)\end{array}$ & $\begin{array}{c}\text { Leaf Fresh } \\
\text { Biomass } \\
\left(\text { g plant }^{-1}\right)\end{array}$ & $\begin{array}{l}\text { Stem Fresh } \\
\text { Biomass } \\
\left(\mathrm{g} \mathrm{plant}^{-1}\right)\end{array}$ & $\begin{array}{c}\text { Root Fresh } \\
\text { Biomass } \\
\left(\text { g plant }^{-1}\right)\end{array}$ & $\begin{array}{c}\text { Total Dry } \\
\text { Biomass } \\
\left.\text { (g plant }^{-1}\right)\end{array}$ & $R / S$ \\
\hline $100 \%$ FC & $17.2 \pm 0.3^{a}$ & $4.6 \pm 0.1^{\mathrm{a}}$ & $15.8 \pm 0.4^{\mathrm{a}}$ & $210.4 \pm 4.5^{\mathrm{a}}$ & $7.6 \pm 0.2^{a}$ & $2.7 \pm 0.2^{\mathrm{a}}$ & $7.8 \pm 0.6^{\mathrm{a}}$ & $2.1 \pm 0.1^{\mathrm{a}}$ & $0.5 \pm 0.0^{b}$ \\
\hline $75 \% \mathrm{FC}$ & $15.8 \pm 0.8^{a b}$ & $4.6 \pm 0.0^{\mathrm{a}}$ & $14.8 \pm 0.4^{\mathrm{a}}$ & $218.5 \pm 6.4^{\mathrm{a}}$ & $8.1 \pm 0.7^{\mathrm{a}}$ & $2.8 \pm 0.2^{\mathrm{a}}$ & $7.7 \pm 0.6^{a}$ & $2.6 \pm 0.0^{\mathrm{a}}$ & $0.7 \pm 0.0^{b}$ \\
\hline $50 \% \mathrm{FC}$ & $14.2 \pm 0.3^{\mathrm{b}}$ & $3.6 \pm 0.2^{b}$ & $13.8 \pm 0.6^{\mathrm{a}}$ & $166.2 \pm 9.2^{b}$ & $5.5 \pm 0.3^{b}$ & $1.7 \pm 0.1^{b}$ & $6.0 \pm 0.3^{a}$ & $1.9 \pm 0.3^{\mathrm{a}}$ & $1.1 \pm 0.2^{\mathrm{a}}$ \\
\hline $25 \% \mathrm{FC}$ & $10.7 \pm 0.2^{c}$ & $2.9 \pm 0.2^{b}$ & $9.7 \pm 0.4^{b}$ & $104.4 \pm 5.5^{c}$ & $3.6 \pm 0.3^{c}$ & $1.1 \pm 0.1^{c}$ & $3.0 \pm 0.5^{b}$ & $1.0 \pm 0.1^{\mathrm{b}}$ & $0.4 \pm 0.0^{b}$ \\
\hline Significance & $* * *$ & $* * *$ & $* * *$ & $* * *$ & $* * *$ & $* *$ & $* * *$ & $* *$ & $*$ \\
\hline
\end{tabular}

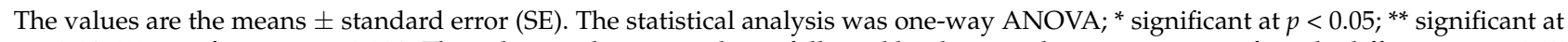
$p<0.01$; ${ }^{* * *}$ significant at $p<0.001$. The values in the same column followed by the same letter are not significantly different at $p<0.05$ (Tukey's test).

A similar trend was detected for the leaf and stem fresh weight, with a reduction of $28 \%$ (leaf) and 15\% (stem) and 56\% (leaf) and 44\% (stem), respectively, for 50\% FC and 25\% FC $(p<0.001$ and $p<0.01)$. The light deficit treatments $(75 \%$ FC) showed the same trend as unstressed plants. Root fresh biomass was only modified in $25 \%$ FC, with a reduction of $54 \%$ compared with the other treatments $(p<0.001)$ (Table 1$)$. In addition, the the total dry biomass decreased only in $25 \%$ FC (by $\sim 48 \%$ ) $(p<0.01)$ compared with the other treatments (Table 1). The root-to-shoot ratio increased in plants grown under moderate deficit irrigation treatments $(50 \%$ FC) $(p<0.05)$ (Table 1$)$.

Stomata density showed significant differences among the irrigation treatments, with an increase in the more severe drought stress (50\% FC and 25\% FC) (Table 2). The drought 
stress influenced the stomata size only in $25 \%$ FC. The latter showed a significant reduction of $31 \%$ compared with $100 \%$ FC and $75 \%$ FC. The $50 \%$ FC treatment did not show a significant change among treatments (Table 2 and Figure 2).

Table 2. Effects of irrigation treatments on stomata density $\left(\mathrm{n} \mathrm{mm}^{-2}\right)$ and size $(\mu \mathrm{m})$ of potted zinnia plants at the end of the experimental period. Plants were irrigated every day. Four treatments were performed: irrigated at $100 \%$ (100\% FC); light deficit irrigation ( $75 \%$ FC), irrigated at $75 \%$ from the $100 \%$ FC treatment; medium deficit irrigation (50\% FC), irrigated at 50\% from the $100 \%$ FC treatment and severe deficit irrigation (25\% FC), and irrigated at $25 \%$ from the $100 \%$ FC treatment.

\begin{tabular}{|c|c|c|}
\hline \multirow{2}{*}{ Drought Stress } & \multicolumn{2}{|c|}{ Stomata } \\
\hline & Density $\left(\mathrm{n} \mathrm{mm}^{-2}\right)$ & Size $(\mu \mathrm{m})$ \\
\hline $100 \% \mathrm{FC}$ & $321.8 \pm 25.2^{b}$ & $84.8 \pm 1.7^{a}$ \\
\hline $75 \% \mathrm{FC}$ & $253.8 \pm 23.9^{b}$ & $83.8 \pm 4.8^{\mathrm{a}}$ \\
\hline $50 \% \mathrm{FC}$ & $376.2 \pm 9.7^{\mathrm{a}}$ & $72.4 \pm 0.6^{\mathrm{ab}}$ \\
\hline $25 \% \mathrm{FC}$ & $396.2 \pm 8.0^{\mathrm{a}}$ & $55.7 \pm 0.1^{b}$ \\
\hline Significance & * & $* *$ \\
\hline
\end{tabular}

The values are the means \pm standard error (S.E). The statistical analysis was one-way ANOVA; ${ }^{*}$ significant at $p<0.05$; ** significant at $p<0.01$. The values in the same column followed by the same letter are not significantly different at $p<0.05$ (Tukey's test).

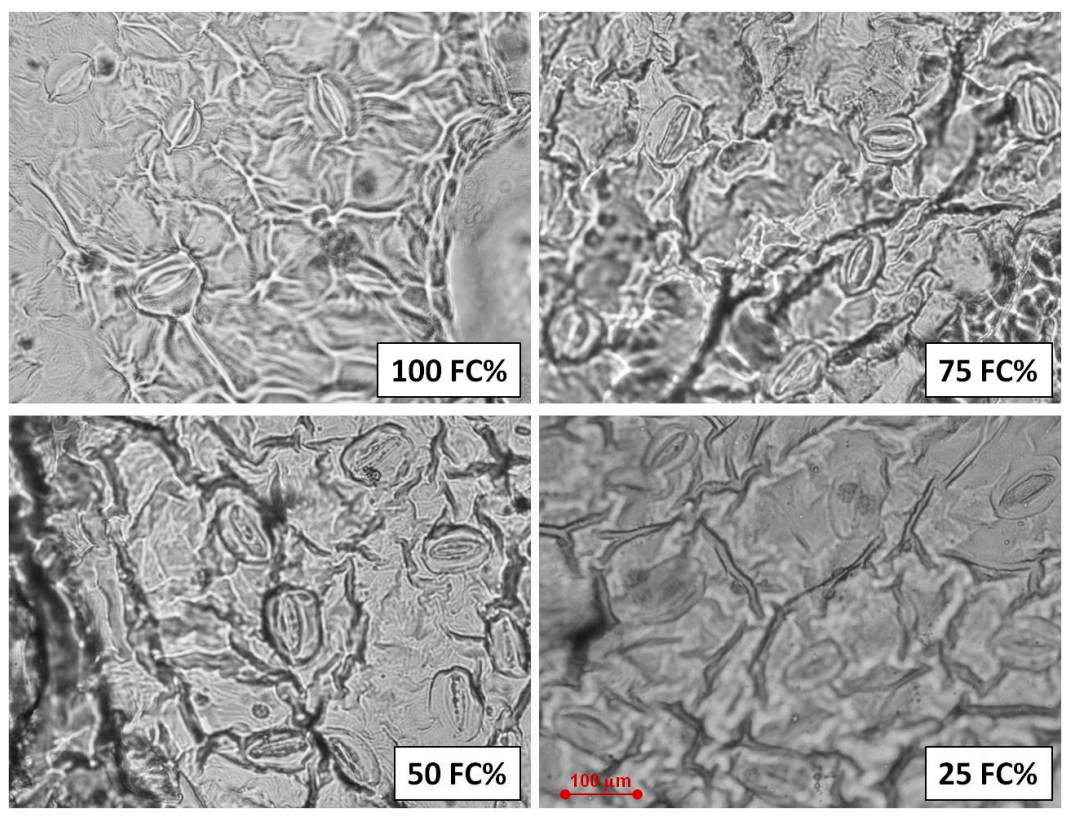

Figure 2. Light microscopy of leaf portions showing stomata traits in different drought stress treatments.

Significant effects of drought stress treatments for gas exchange were observed in zinnia plants (Figure 3). The net photosynthesis, stomatal conductance, and transpiration rate showed similar behaviours. Significant differences for $A_{N}$ were observed in the $50 \%$ FC and 25\% FC treatments compared with the control plants and 75\% FC. In particular, the plants irrigated at $50 \%$ FC and $25 \%$ FC showed a reduction of $~ 30 \%$ and $66 \%$ compared with control plants (Figure 3a). A similar trend was observed for the stomatal conductance, with a reduction of $\sim 51 \%$ and $80 \%$, respectively, for $50 \%$ FC and $25 \%$ FC (Figure $3 b$ ) compared with the control and $75 \%$ FC. The transpiration rate showed a significant reduction only in the severe drought stress treatment, with a reduction of $61 \%$ compared with $100 \%$ FC and the other stress treatments. (Figure 3c). Water use efficiency (WUE) showed significant differences among the more stressed treatment $(25 \% \mathrm{FC})$ and the other treatments with an increase of $\sim 45 \%$ (Figure $3 \mathrm{~d}$ ). 


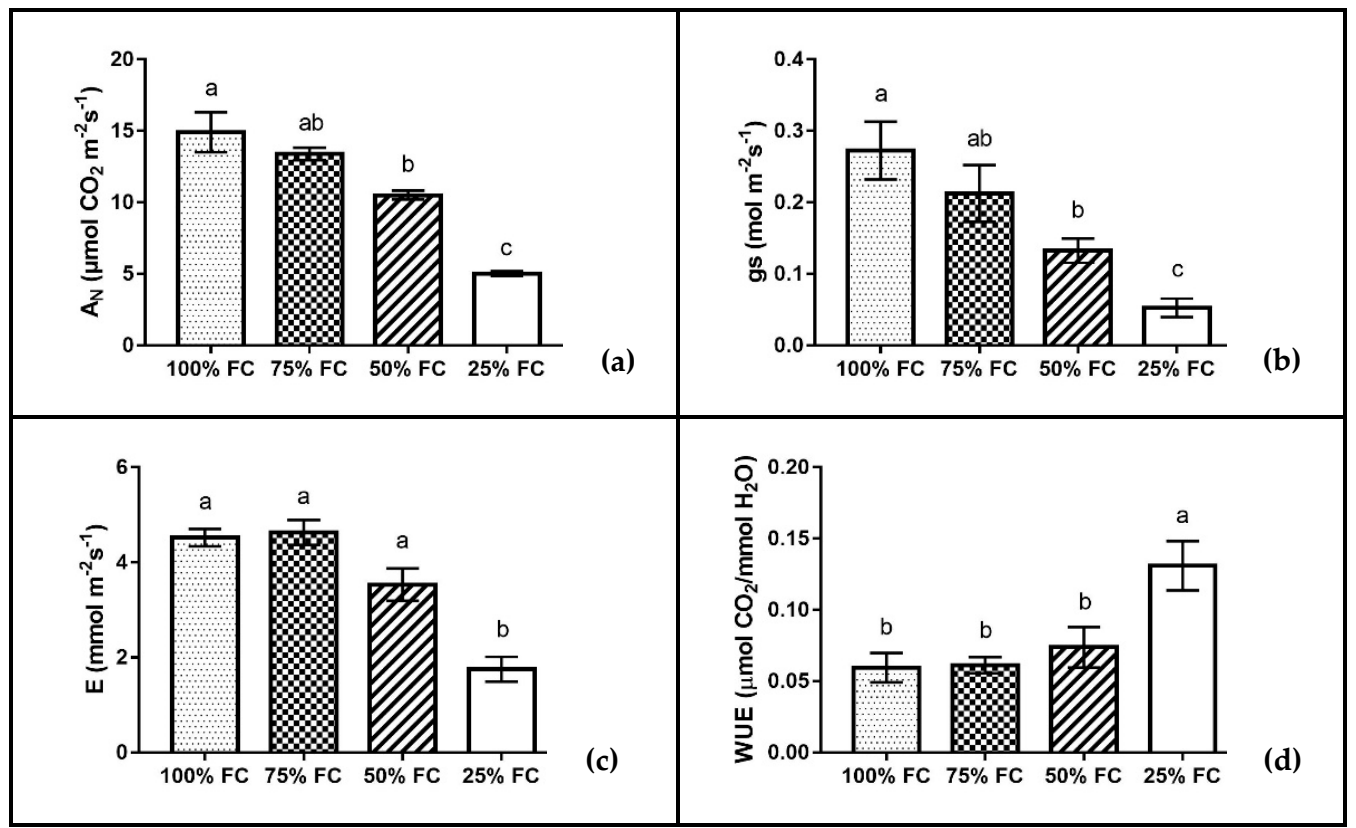

Figure 3. Net photosynthesis $\left(\mathrm{A}_{\mathrm{N}}\right)(\mathbf{a})$, leaf conductance $(\mathrm{gs})(\mathbf{b})$, transpiration rate $(\mathrm{E})(\mathbf{c})$, and water use efficiency (WUE) (d) in zinnia. Plants were irrigated at field capacity (100\% FC) or subjected to drought stress (75\% FC, 50\% FC, and 25\% FC). Mean values \pm standard error (S.E) $(n=6)$. Different letters indicate significant differences among the treatments as determined by Tukey's test.

Significant differences for $\mathrm{Chl} a$ and $b$, total $\mathrm{Chl}$, and carotenoids were observed in the $25 \%$ FC treatment. In particular, the plants irrigated at 25\% FC showed reductions of $\sim 36 \%$, $39 \%, 37 \%$, and $40 \%$, respectively, for $\mathrm{Chl} a$ and $b$, total $\mathrm{Chl}$, and carotenoids compared with control plants (Figure $4 \mathrm{a}-\mathrm{d}$ ). Among the other treatments, no significant differences were observed (Figure 4a-d).

The RWC under light and moderate drought stress (75\% FC and 50\% FC) did not show significant differences compared with control plants and the other treatments. In the condition of severe drought stress ( $25 \%$ FC), a significant reduction of $\sim 32 \%$ was observed (Table 3).

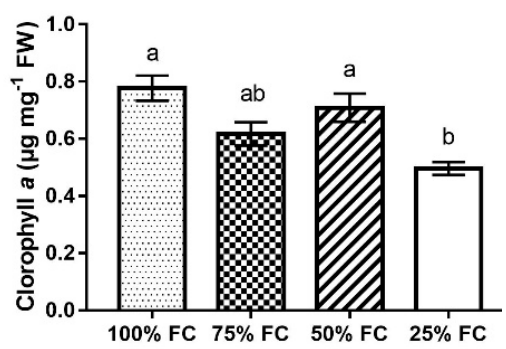

(a)

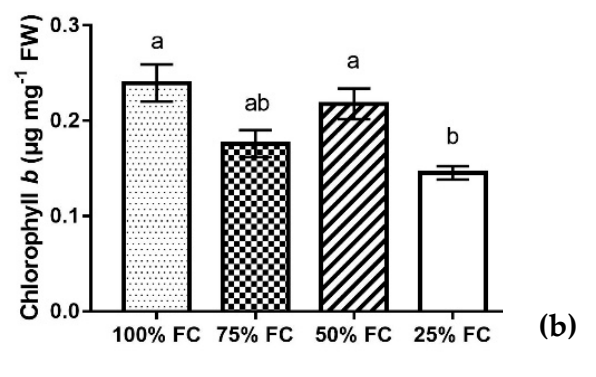

Figure 4. Cont. 


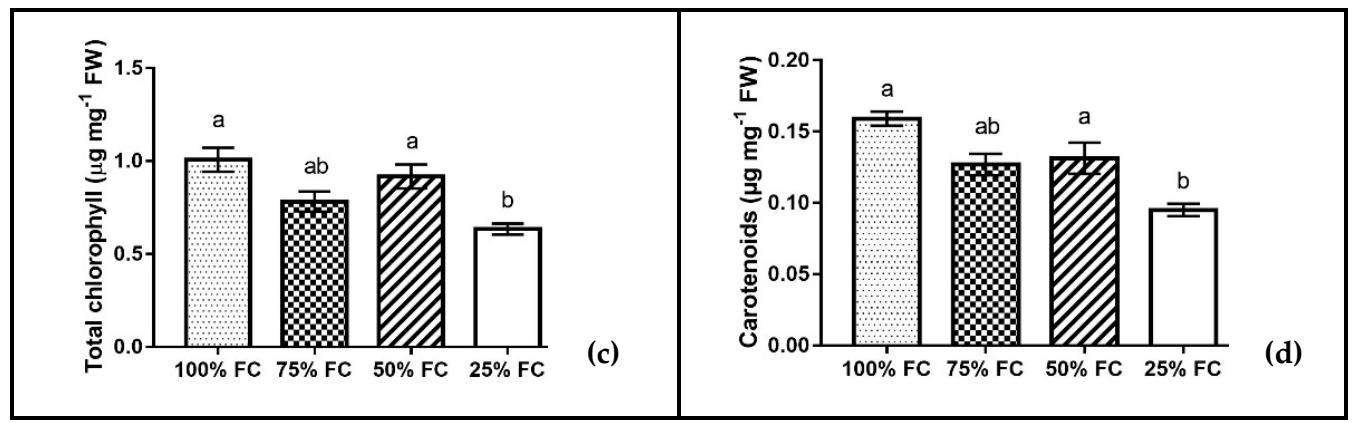

Figure 4. Chlorophyll $a(\mathbf{a})$, chlorophyll $b(\mathbf{b})$, total chlorophyll (c), and carotenoids (d) in zinnia plants. Plants were irrigated at field capacity (100\% FC) or subjected to drought stress (75\% FC, 50\% FC, and $25 \%$ FC). Mean values \pm standard error $(S . E)(n=6)$. Different letters indicate significant differences among the treatments as determined by Tukey's test.

Table 3. Effects of irrigation treatments on relative water content (RWC, \%) and chlorophyll $a$ fluorescence $(\mathrm{Fv} / \mathrm{Fm})$ of potted zinnia plants at the end of the experimental period. Plants were irrigated every day. Four treatments were performed: irrigated at $100 \%$ (100\% FC); light deficit irrigation (75\% FC), irrigated at 75\% from the 100\% FC treatment; medium deficit irrigation ( $50 \%$ FC), irrigated at $50 \%$ from the $100 \%$ FC treatment and severe deficit irrigation (25\% FC), irrigated at $25 \%$ from the $100 \%$ FC treatment.

\begin{tabular}{ccc}
\hline Drought Stress & RWC (\%) & Fv/Fm \\
\hline $100 \%$ FC & $73.8 \pm 3.1^{\mathrm{a}}$ & $0.74 \pm 0.01^{\mathrm{a}}$ \\
$75 \%$ FC & $66.7 \pm 2.7^{\mathrm{a}}$ & $0.73 \pm 0.00^{\mathrm{a}}$ \\
$50 \%$ FC & $66.7 \pm 2.9^{\mathrm{a}}$ & $0.72 \pm 0.02^{\mathrm{ab}}$ \\
$25 \%$ FC & $50.7 \pm 1.5^{\mathrm{b}}$ & $0.68 \pm 0.02^{\mathrm{b}}$ \\
Significance & $* *$ & $*$
\end{tabular}

The values are the means \pm standard error (SE). The statistical analysis was one-way ANOVA; * significant at $p<0.05$; ${ }^{* *}$ significant at $p<0.01$. The values in the same column followed by the same letter are not significantly different at $p<0.05$ (Tukey's test).

In zinnia plants, a reduction in the maximum quantum efficiency $(\mathrm{Fv} / \mathrm{Fm})$ was observed only in severe drought stress conditions ( $10 \% \mathrm{FC})$, with a value of 0.68 (Table 3).

The amount of leaf proline content increased in $25 \%$ FC. Severe drought stress ( $25 \%$ FC) increased proline content up to seven-fold compared with the control plants (Figure 5a). Among the other treatments, no significant differences were observed (Figure 5a).

The MDA content did not show a significant change among treatments (Figure $5 b$ ).

The results showed that drought stress significantly affected enzyme activity (Table 4). The CAT activity significantly increased in moderate and severe drought stress (50\% FC and $25 \%$ FC). The increment was $41 \%$ for CAT and 33\% for GPX. In addition, SOD activity showed a similar trend: an increase of $42 \%$ in 50\% FC and $25 \%$ FC was observed (Table 4).

The results showed that drought stress significantly affected DPPH activity $(p \leq 0.01)$. DPPH activity significantly increased with severe drought stress treatment. The increment from control to $25 \%$ FC was $\sim 23 \%$, while among the other treatments, no significant differences were observed (Table 4).

In order to visualise congruence among $100 \% \mathrm{FC}, 75 \% \mathrm{FC}, 50 \% \mathrm{FC}$, and $25 \% \mathrm{FC}$ plants based on all of the morphological, physiological, and biochemical variables, the whole dataset was subjected to a principal component analysis (PCA; Figure 6). The PCA showed that the morphological and physiological parameters were mostly associated with the $100 \% \mathrm{FC}$ and $75 \% \mathrm{FC}$ treatments of the biplot, whereas the stomata density, R/S ratio, and antioxidant enzymes (GPX, CAT) were associated with the 50\% FC treatment, and proline and DPPH were associated with the $25 \%$ FC treatment (Figure 6). 


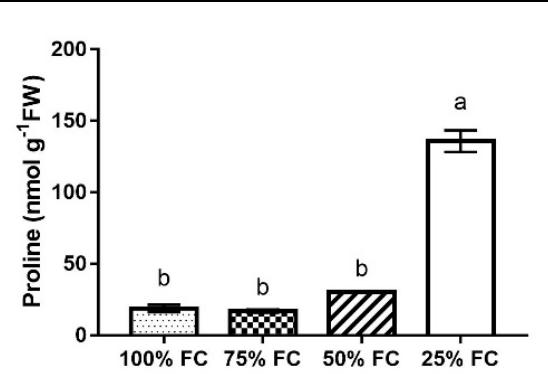

(a)

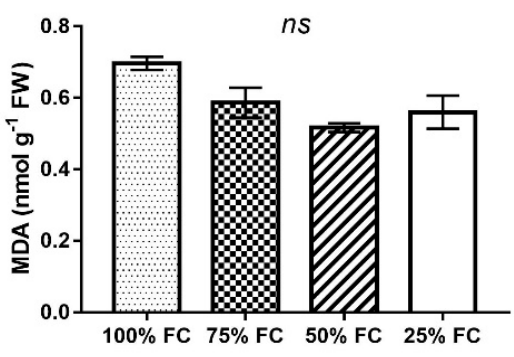

Figure 5. Proline content (a) and malondialdehyde content (MDA) (b) in zinnia plants. Plants were irrigated at field capacity (100\% FC) or subjected to drought stress (75\% FC, 50\% FC, and 25\% FC). Mean values \pm standard error (S.E) $(n=6)$. Different letters indicate significant differences among the treatments as determined by Tukey's test. ns: no significant.

Table 4. Effects of irrigation treatments on catalase (CAT), peroxidase (GPX), and superoxide dismutase (SOD) activity of potted zinnia plants at the end of the experimental period. Plants were irrigated every day. Four treatments were performed: irrigated at 100\% (100\% FC), light deficit irrigation (75\% FC), irrigated at $75 \%$ from the $100 \%$ FC treatment; medium deficit irrigation ( $50 \%$ FC), irrigated at $50 \%$ from the $100 \%$ FC treatment and severe deficit irrigation ( $25 \% \mathrm{FC}$ ), irrigated at $25 \%$ from the $100 \%$ FC treatment.

\begin{tabular}{|c|c|c|c|c|}
\hline \multirow[b]{2}{*}{ Drought Stress } & \multicolumn{3}{|c|}{ Enzyme Activity } & \multirow[b]{2}{*}{$\begin{array}{c}\text { DPPH } \\
\left(\mathrm{mg} \mathrm{TE}^{-1} \mathrm{FW}\right)\end{array}$} \\
\hline & $\begin{array}{c}\text { CAT } \\
\text { (U mg }^{-1} \\
\text { Protein) }\end{array}$ & $\begin{array}{c}\text { GPX } \\
\text { (U mg }^{-1} \\
\text { Protein) }\end{array}$ & $\begin{array}{c}\text { SOD } \\
\text { (U mg-1 } \\
\text { Protein) }\end{array}$ & \\
\hline $100 \% \mathrm{FC}$ & $0.0040 \pm 0.0005^{b}$ & $5.6 \pm 0.6^{b}$ & $29.5 \pm 0.2^{b}$ & $6.7 \pm 0.1^{b}$ \\
\hline $75 \% \mathrm{FC}$ & $0.0042 \pm 0.0008^{b}$ & $5.9 \pm 0.4^{b}$ & $23.4 \pm 0.1^{\mathrm{b}}$ & $6.9 \pm 0.1^{b}$ \\
\hline $50 \% \mathrm{FC}$ & $0.0069 \pm 0.0003^{a}$ & $8.0 \pm 0.9^{\mathrm{a}}$ & $45.8 \pm 3.3^{a}$ & $6.7 \pm 0.2^{b}$ \\
\hline $25 \% \mathrm{FC}$ & $0.0072 \pm 0.0001^{\mathrm{a}}$ & $9.2 \pm 0.5^{\mathrm{a}}$ & $44.0 \pm 1.5^{\mathrm{a}}$ & $8.6 \pm 0.4^{\mathrm{a}}$ \\
\hline Significance & $* *$ & $* *$ & $* * *$ & $* * *$ \\
\hline
\end{tabular}

The values are the mean \pm standard error (S.E). The statistical analysis was one-way ANOVA; ${ }^{* *}$ significant at $p<0.01$; ${ }^{* * *}$ significant at $p<0.001$. The values in the same column followed by the same letter are not significantly different at $p<0.05$ (Tukey's test).

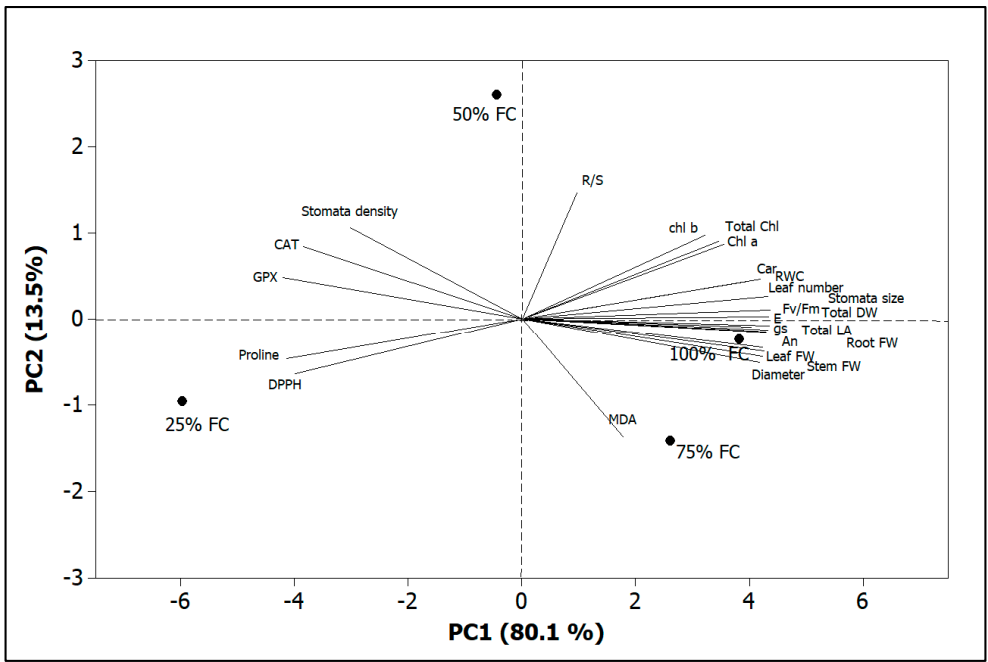

Figure 6. Principal component loading plot and scores of PCA fresh weight and dry biomass, R/S, total leaf area, leaf number, photosynthetic pigments (Chl $a$ and $b$, total $\mathrm{Chl}$, and carotenoids), stomata characteristics, gas exchange, RWC, Fv / Fm, MDA, proline (Pro), enzyme activity (GPX, CAT. and SOD), and DPPH for zinnia plants with different drought stress treatments (100\% FC, 75\% FC, 50\% FC, and 25\% FC) according to the first two principal components. 


\section{Discussion}

Drought tolerance is the capacity of plants to continue to be functional at lower tissue water potentials. Drought stress determines considerable changes in the physiological and biochemical activity of plants, including photosynthesis, respiration, transpiration, hormone metabolism, and enzyme activity [45]. The mechanisms of drought tolerance involve the maintenance of turgor (by the accumulation of solutes) and/or desiccation tolerance (by protoplasmic resistance) [46]. In urban areas, it is important to select species for planting that are able to tolerate water shortages without losing their aesthetic appearance [47]. Water availability is one of the principal factors that limit bedding and landscaping plant cultivation, particularly for seasonal and annual garden flowers with shallow roots [1]. In the nursery phase, the generalised use of containers, often of small volume, determines root restriction effects [35].

Because of the showiness of flowering herbaceous species, it is difficult to convince people not to use them in urban landscaping. These plants are particularly sensitive to water deficiency. Annual plants are vulnerable to increasing temperatures and decreasing rainfall, as they must complete their life cycle in a single season, and the persistence of the population is highly dependent on the reproductive capacity of a season [48]. As for woody plants, herbaceous plants also adopt different physiological and biochemical mechanisms to overcome drought stress. One of the first responses to drought stress is a reduction in plant growth. In our study, the drought stress treatments significantly reduced the height, shoot and root dry biomass, leaf number, and leaf area in the more stressed treatments. A moderate reduction in the amount of water applied to container-grown zinnias did not reduce the morpho-biometric characteristics. Previous studies have shown that dry biomass reduced significantly with increasing drought stress treatments in Trachyspermum ammi L. [49] and Ocimum basilicum L. [50]. At the end of the drought treatment, the plant biomass reduction could be linked to a reduction in cell elongation and expansion; lower water absorption led to a reduction in the production of metabolites to maintain normal cellular activity [51].

A lower water amount can have positive effects on growth, so light drought stress can be a useful water-saving strategy. In our study, the plants grown at 50\% FC showed no reduction in growth parameters. In a study on parsley, Borges et al. [52] demonstrated that water reduction significantly modified the development of the aerial parts. According to Zulfiqar et al. [53], a reduction in biomass is a good strategy in Tagetes erecta to improve water uptake under drought stress in the long term. Drought stress influences the aerial parts of the plants more than the roots; furthermore, the growth of the aerial parts of the plant decreases earlier than the roots, causing an increased root-to-shoot ratio. This ratio is not always modified by drought stress. Sánchez-Blanco et al. [54] found that the R/S in Pistacia lentiscus and Phillyrea angustifolia was not influenced under water stress treatments. In our study, except for $50 \%$ FC, the same trend was observed. Eziz et al. [55], in a meta-analysis to explain the patterns of plant biomass allocation related to drought stress, found that roots of woody plants were more resistant than those of herbaceous plants to drought. Furthermore, drought stress in herbaceous plants had a more negative influence on the leaf mass fraction of woody plants. In our study, leaf fresh biomass reduced as water stress increased. A similar response was observed for the total leaf area and leaf number. The reduction of the leaf area is due to a reduction in the leaf number [36] or leaf size (unit leaf area) [56]. Thus, plants decrease water limitation by reducing the transpiration area. This is a typical mechanism of stress avoidance used by plants to overcome water stress conditions [57].

The gas exchange rates are most affected by water shortage. The principal site of stress in the plants is the photosynthetic apparatus, which is very sensitive to drought; as a consequence, the photosynthetic activity is reduced because of stomatal closure and complex non-gassing effects [58]. In the present study, $A_{N}$, gs, and E significantly decreased in the leaves of zinnia under moderate and severe drought stress, and $A_{N}$ decreased substantially in $25 \% \mathrm{FC}$, indicating that the reduction in $\mathrm{A}_{\mathrm{N}}$ in the first stage might be 
determined by the stomatal closure inhibition of $\mathrm{CO}_{2}$ uptake. Drake et al. [59] suggested that many small stomata lead to greater stomatal resistance and stomatal control, as well as a rapid response in water stress conditions. In our study, in the more stressed treatments (50\% FC and 25\% FC), an increase in stomata density and a decrease in size were observed. With the reduction of transpiration, the water use efficiency generally increases. Different studies have reported that stressed plants are more able to utilise the energy obtained by photosynthesis because of higher WUE [57]. This is in accordance with our results, which showed that the most stressed plants activated this mechanism by increasing the WUE values. Another typical avoidance strategy during drought stress conditions is a change in the size and density of the stomata [57].

A high RWC during drought stress is a key mechanism for maintaining the metabolic activity in plants; it is a well-known mechanism for inducing drought tolerance in breeding activity [60]. Babaei et al. [61], in a study on Tagetes minuta, noted that the low RWC values in this species during drought showing a low recovery capacity. A higher RWC is generally maintained by plants under moderate drought stress in relation to plants under severe drought stress. Furthermore, the growth parameters were more negatively influenced by the imposed water stress than they were in zinnia with higher RWC values.

Chlorophylls are responsible for the correct functioning of the photosynthetic apparatus because they are essential pigments of the superior assimilating tissues of plants. Under salt or water stress, the pigment photosynthetic (chlorophyll $a+b$ ) content can be indicative of stressful conditions [62]. Severe drought stress can also impair the concentrations of photosynthetic pigments [63]. A decrease in chlorophyll content under severe water stress has been noted in different species, including Catharanthus roseus [64], Helianthus annuus [65], Tagetes erecta [66], and Viola $x$ witthrockiana [67]. In our study, the effects of the severe drought stress (25\% FC), were highlighted in the leaves by a significant lowering of the chlorophyll $a$ and $b$, total chlorophyll, and carotenoid content. A physiological adaptation mechanism of plants under drought stress conditions could be the maintenance of high chlorophyll content, even if this is correlated with the biological characteristics of the plant [68]. Indeed, Lu et al. [69] observed that increasing the chlorophyll content was a more effective strategy to avoid photooxidation damage and ROS induction by drought. Plants under drought stress typically accumulate osmotic compounds, such as proline, and change phytohormones [18]. Proline has been found to enhance cell turgor, maintain cell osmotic adjustment, and defend cells during dehydration [67]. In our study, it was noted that proline concentration was higher in zinnia plants under severe drought conditions compared with control plants. These results agree with the results of other studies [70] and underline the relevance of proline as a protective element in the stress response [71]. In addition, Oraee et al. [72] showed that the proline concentration was higher in plants under drought treatments compared with well-watered plants. In drought stress conditions, proline accumulation was inversely proportional to the water status of plants [73]; this was confirmed in our study, in which the highest values of proline in $25 \%$ FC corresponded to the lowest values of RWC. This suggests the contribution of this solute in plant osmotic adjustment. Similarly, in Indian grain soybean cultivars exposed to mild water stress, an increased proline accumulation corresponded to a smaller reduction in the relative water content and shoot and root fresh/dry weight [74].

Plants, when synthesizing antioxidants and increasing the activity of antioxidative enzymes, activate a protective mechanism against abiotic stress [75]. Antioxidative enzymes that control ROS level in cells-superoxide dismutase (SOD), catalase (CAT), and peroxidase (POX) - are commonly produced in response to drought. Numerous studies have found that drought-tolerant plants have strong scavenging systems that allow them to maintain low levels of ROS and reduce membrane lipid peroxidation during stress [22].

Among the antioxidative enzymes that act in scavenging ROS species, APX, SOD, and GPX have a key role. Ascorbate peroxidase (APX) acts directly on the $\mathrm{H}_{2} \mathrm{O}_{2}$ molecules and reduces them to water. SOD conducts the dismutation reaction by reducing the $\mathrm{O}^{-2}$ molecule to $\mathrm{H}_{2} \mathrm{O}_{2}$; APX and GPX convert $\mathrm{H}_{2} \mathrm{O}_{2}$ to water, thus assuring its removal [76]. In 
this study, plants under 50\% FC and 25\% FC showed a significant increment in antioxidant activity at the end of the trial. CAT, SOD, and GPX activity was significantly enhanced at moderate and severe drought stress (50\% FC and 25\% FC). A similar trend was reported by Amiri et al. [77]. In a study by Tian et al. [78], the results indicated that the increase in enzyme activity in marigold was a tolerant response to drought treatment, while this self-regulation level was lower with the improvement of water deficit. The decrease in CAT activity leads to the accumulation of $\mathrm{H}_{2} \mathrm{O}_{2}$ and an enhancement in lipid peroxidation, thus increasing MDA and causing damage in plants [78]. Recent studies have observed that proline may also play a role as an antioxidant and not only as an osmotic protectant. Thus, the accumulation of proline plays a key role under drought stress as an antioxidant or through stabilizing macromolecules during water stress [79]. The enhancement of DPPH activity observed in the more stressed plants is in line with other studies $[61,80]$. The total antioxidant activity is the combined results of all enzymatic and non-enzymatic antioxidant activity in plants subjected to abiotic stresses. Tolerant plants generally show a higher antioxidant content to defend against oxidative stress by keeping high antioxidant enzyme and antioxidant molecule activity and contents under stress conditions [81].

Through the general analysis of the data, we observed an interesting result that the activity of antioxidant enzymes is strongly linked to the increase of secondary metabolites; this is similar to the findings of Catola et al. [82] that secondary metabolites work as substrates for enzymes involved in enzymatic antioxidant reactions [51]. The PCA analysis reported in the present study could help to better understand the influence of drought stress on morphological, physiological, and biochemical characteristics. The PCA results demonstrated the boundary between the drought treatments and the control group was clear. Correlation analysis demonstrated that there were complex and close relationships in the more stressed treatments (50\% FC and $25 \%$ FC) between the antioxidant enzyme activity, DPPH, proline accumulation, and stomata density, which cooperated to tolerate drought stress. The sensitivity of zinnia plants to drought stress is different, so the response time is also different.

\section{Conclusions}

The changes in growth parameters, stomata characteristics, gas exchange, osmotic regulators, and antioxidant activity were measured to study the response mechanism of $Z$. elegans to drought stress. During drought exposure in the nursery phase, zinnia showed adaptive changes to water limitation. At the physiological level, zinnia responded to the drought stress by reducing the RWC and biomass and increasing the levels of osmotic regulators (proline) and antioxidant activity. In severe deficit irrigation, the strategies adopted by the plants were not able to resist drought stress. With light deficit irrigation, the plants could perform as well as fully irrigated plants. In medium deficit irrigation, the mechanisms were not always are suitable to overcome drought stress.

Author Contributions: Conceptualization, D.R. and S.T.; methodology, D.R. and S.T.; software, S.T.; validation, D.R.; formal analysis, S.T.; investigation, S.T.; resources, D.R.; data curation, S.T.; writingoriginal draft preparation, D.R. and S.T.; writing—review and editing, D.R. and S.T.; supervision, D.R.; funding acquisition, D.R. Both authors have read and agreed to the published version of the manuscript.

Funding: This research was funded by PON RICERCA E INNOVAZIONE 2014-2020, Azione IIObiettivo Specifico $1 \mathrm{~b}$-Progetto "Miglioramento delle produzioni agroalimentari mediterranee in condizioni di carenza di risorse idriche-WATER4AGRIFOOD", cod. progetto ARS01_00825.

Institutional Review Board Statement: Not applicable.

Informed Consent Statement: Not applicable.

Data Availability Statement: Main data are contained within the article; further data presented in this study are available on request from the corresponding author.

Conflicts of Interest: The authors declare no conflict of interest. 


\section{References}

1. Heidari, Z.; Nazarideljou, M.J.; Rezaie Danesh, Y.; Khezrinejad, N. Morphophysiological and biochemical responses of Zinnia elegans to different irrigation regimes in symbiosis with Glomus mosseae. Int. J. Hortic. Sci. 2016, 3, 19-32. [CrossRef]

2. Da Silva, F.F.; Wallach, R.; Chen, Y. Hydraulic properties of sphagnum peat moss and tuff (scoria) and their potential effects on water availability. In Optimization of Plant Nutrition; Springer: Berlin/Heidelberg, Germany, 1993; pp. 569-576.

3. Talbi, S.; Rojas, J.A.; Sahrawy, M.; Rodríguez-Serrano, M.; Cárdenas, K.E.; Debouba, M.; Sandalio, L.M. Effect of drought on growth, photosynthesis and total antioxidant capacity of the Saharan plant Oudeneya africana. Environ. Exp. Bot. 2020, 176, 104099. [CrossRef]

4. Larkunthod, P.; Nounjan, N.; Siangliw, J.L.; Toojinda, T.; Sanitchon, J.; Jongdee, B.; Theerakulpisut, P. Physiological responses under drought stress of improved drought-tolerant rice lines and their parents. Not. Bot. Horti Agrobot. Cluj Napoca 2018, 46, 679-687. [CrossRef]

5. Cal, A.J.; Sanciangco, M.; Rebolledo, M.C.; Luquet, D.; Torres, R.O.; McNally, K.L.; Henry, A. Leaf morphology, rather than plant water status, underlies genetic variation of rice leaf rolling under drought. Plant. Cell Environ. 2019, 42, 1532-1544. [CrossRef]

6. Jaramillo, R.E.; Nord, E.A.; Chimungu, J.G.; Brown, K.M.; Lynch, J.P. Root cortical burden influences drought tolerance in maize. Ann. Bot. 2013, 112, 429-437. [CrossRef]

7. Nemali, K.S.; Bonin, C.; Dohleman, F.G.; Stephens, M.; Reeves, W.R.; Nelson, D.E.; Castiglioni, P.; Whitsel, J.E.; Sammons, B.; Silady, R.A.; et al. Physiological responses related to increased grain yield under drought in the first biotechnology-derived drought tolerant maize. Plant Cell Environ. 2015, 38, 1866-1880. [CrossRef]

8. Tezara, W.M.V.J.; Mitchell, V.J.; Driscoll, S.D.; Lawlor, D.W. Water stress inhibits plant photosynthesis by decreasing coupling factor and ATP. Nature 1999, 401, 914-917. [CrossRef]

9. Kim, J.; van Iersel, M.W. Slowly developing drought stress increases photosynthetic acclimation of Catharanthus roseus. Physiol. Plant. 2011, 143, 166-177. [CrossRef]

10. Nemali, K.; van Iersel, M.W. Relating whole-plant photosynthesis to physiological acclimations at leaf and cellular scales under drought stress in bedding plants. J. Am. Soc. Hortic. Sci. 2019, 144, 201-208. [CrossRef]

11. Chaves, M.M.; Maroco, J.P.; Pereira, J.S. Understanding plant responses to drought from genes to the whole plant. Funct. Plant Biol. 2003, 30, 239-264. [CrossRef]

12. Boyle, R.K.; McAinsh, M.; Dodd, I.C. Stomatal closure of Pelargonium $\times$ hortorum in response to soil water deficit is associated with decreased leaf water potential only under rapid soil drying. Physiol. Plant. 2016, 156, 84-96. [CrossRef] [PubMed]

13. Sanders, G.J.; Arndt, S.K. Osmotic adjustment under drought conditions. In Plant Responses to Drought Stress; Aroca, R., Ed.; Springer: Berlin/Heidelberg, Germany, 2012; pp. 199-229. [CrossRef]

14. Nemali, K.S.; Stephens, M. Plant abiotic stress: Water. In Encyclopedia of Agriculture and Food Systems; Van Alfen, N.K., Ed.; Elsevier: London, UK, 2014; pp. 335-342.

15. Flexas, J.; Escalona, J.M.; Medrano, H. Water stress induces different levels of photosynthesis and electron transport rate regulation in grapevines. Plant Cell Environ. 1999, 22, 39-48. [CrossRef]

16. Fu, J.; Huang, B. Involvement of antioxidants and lipid peroxidation in the adaptation of two cool-season grasses to localized drought stress. Environ. Exp. Bot. 2001, 45, 105-114. [CrossRef]

17. Dias, M.C.; Correia, S.; Serôdio, J.; Silva, A.M.S.; Freitas, H.; Santos, C. Chlorophyll fluorescence and oxidative stress endpoints to discriminate olive cultivars tolerance to drought and heat episodes. Sci. Hortic. 2018, 231, 31-35. [CrossRef]

18. Hare, P.D.; Cress, W.A.; Van Staden, J. The involvement of cytokinins in plant responses to environmental stress. Plant Growth Regul. 1997, 23, 79-103. [CrossRef]

19. Zhang, X.; Ervin, E.H.; Evanylo, G.K.; Haering, K.C. Impact of biosolids on hormone metabolism in drought-stressed tall fescue. Crop. Sci. 2009, 49, 1893-1901. [CrossRef]

20. Zali, A.G.; Ehsanzadeh, P. Exogenously applied proline as a tool to enhance water use efficiency: Case of fennel. Agric. Water Manag. 2018, 197, 138-146. [CrossRef]

21. Ghaffari, H.; Tadayon, M.R.; Nadeem, M.; Cheema, M.; Razmjoo, J. Proline-mediated changes in antioxidant enzymatic activities and the physiology of sugar beet under drought stress. Acta Physiol. Plant. 2019, 41, 23. [CrossRef]

22. Toscano, S.; Farieri, E.; Ferrante, A.; Romano, D. Physiological and biochemical responses in two ornamental shrubs to drought stress. Front. Plant. Sci. 2016, 7, 645. [CrossRef]

23. Sharma, P.; Jha, A.B.; Dubey, R.S. Oxidative stress and antioxidative defense system in plants growing under abiotic stresses. In Handbook of Plant and Crop Stress, 4th ed.; Pessarakli, M., Ed.; CRC Press: Boca Raton, FL, USA, 2019; pp. 93-136.

24. Caverzan, A.; Passaia, G.; Rosa, S.B.; Ribeiro, C.W.; Lazzarotto, F.; Margis-Pinheiro, M. Plant responses to stresses: Role of ascorbate peroxidase in the antioxidant protection. Genet. Mol. Biol. 2012, 35, 1011-1019. [CrossRef]

25. Moran, J.F.; Becana, M.; Iturbe-Ormaetxe, I.; Frechilla, S.; Klucas, R.V.; Aparicio-Tejo, P. Drought induces oxidative stress in pea plants. Planta 1994, 194, 346-352. [CrossRef]

26. Wang, Y.J.; Wang, L. Characterization of acetylated waxy maize starches prepared under catalysis by different alkali and alkaline-earth hydroxides. Starch-Stärke 2002, 54, 25-30. [CrossRef]

27. Keles, Y.; Öncel, I. Growth and solute composition in two wheat species experiencing combined influence of stress conditions. Russ. J. Plant Physiol. 2004, 51, 203-209. [CrossRef] 
28. Dole, J.M.; Fanelli, F.L.; Fonteno, W.C.; Harden, B.; Blankenship, S.M. Post harvest handling of cut linaria, trachelium, and zinnia. HortScience 2005, 40, 1123B. [CrossRef]

29. Pallavi, B.; Nivas, S.K.; D'souza, L.; Ganapathi, T.R.; Hegde, S. Gamma rays induced variations in seed germination, growth and phenotypic characteristics of Zinnia elegans var. Dreamland. Adv. Hortic. Sci. 2017, 31, 267-274. [CrossRef]

30. Nau, J. Zinnia. In Ball Red Book Greenhouse Growing, 15th ed.; Ball, V., Ed.; J. Ball Publishing: West Chicago, IL, USA, 1991; pp. 785-787.

31. Raza, A.; Razzaq, A.; Mehmood, S.S.; Zou, X.; Zhang, X.; Lv, Y.; Xu, J. Impact of climate change on crops adaptation and strategies to tackle its outcome: A review. Plants 2019, 8, 34. [CrossRef]

32. Lobell, D.B.; Gourdji, S.M. The influence of climate change on global crop productivity. Plant Physiol. 2012, $160,1686-1697$. [CrossRef]

33. Farooq, M.; Wahid, A.; Kobayashi, N.; Fujita, D.; Basra, S.M.A. Plant drought stress: Effects, mechanisms and management. In Sustainable Agriculture; Lichtfouse, E., Navarrete, M., Debaeke, P., Véronique, S., Alberola, C., Eds.; Springer: Dordrecht, The Netherlands, 2009; pp. 153-158. [CrossRef]

34. Niu, G.; Rodriguez, D.S.; Wang, Y.T. Impact of drought and temperature on growth and leaf gas exchange of six bedding plant species under greenhouse conditions. HortScience 2006, 41, 1408-1411. [CrossRef]

35. Toscano, S.; Ferrante, A.; Tribulato, A.; Romano, D. Leaf physiological and anatomical responses of Lantana and Ligustrum species under different water availability. Plant Physiol. Biochem. 2018, 127, 380-392. [CrossRef]

36. Alvarez, S.; Bañón, S.; Sánchez-Blanco, M.J. Regulated deficit irrigation in different phenological stages of potted geranium plants: Water consumption, water relations and ornamental quality. Acta Physiol. Plant. 2013, 35, 1257-1267. [CrossRef]

37. Lichtenthaler, H.K. Chlorophylls and carotenoids: Pigments of photosynthetic biomembranes. Methods Enzymol. 1987, 148, 350-382. [CrossRef]

38. Ahmad, P.; John, R.; Sarwat, M.; Umar, S. Responses of proline, lipid peroxidation and antioxidative enzymes in two varieties of Pisum sativum L. under salt stress. Int. J. Plant Prod. 2008, 2, 353-366.

39. Li, G.; Wan, S.; Zhou, J.; Yang, Z.; Qin, P. Leaf chlorophyll fluorescence, hyperspectral reflectance, pigments content, malondialdehyde and proline accumulation responses of castor bean (Ricinus communis L.) seedlings to salt stress levels. Ind. Crop. Prod. 2010, 31, 13-19. [CrossRef]

40. Bian, S.; and Jiang, Y. Reactive oxygen species, antioxidant enzyme activities and gene expression patterns in leaves and roots of Kentucky bluegrass in response to drought stress and recovery. Sci. Hortic. 2009, 120, 264-270. [CrossRef]

41. Aguilera, J.; Bischof, K.; Karsten, U.; Hanelt, D.; Wiencke, C. Seasonal variation in ecophysiological patterns in macroalgae from an Arctic fjord. II. Pigment accumulation and biochemical defence systems against high light stress. Mar. Biol. 2002, 140, 1087-1095. [CrossRef]

42. Ruley, A.T.; Sharma, N.C.; Sahi, S.V. Antioxidant defense in a lead accumulating plant, Sesbania drummondii. Plant Physiol. Biochem. 2004, 42, 899-906. [CrossRef]

43. Giannopolitis, C.N.; Ries, S.K. Superoxide occurrence in higher plants. Plant Physiol. 1977, 59, 309-314. [CrossRef]

44. Bradford, M.M. A rapid and sensitive method for the quantitation of microgram quantities of protein utilizing the principle of protein-dye binding. Anal. Biochem. 1976, 72, 248-254. [CrossRef]

45. Okunlola, G.O.; Olatunji, O.A.; Akinwale, R.O.; Tariq, A.; Adelusi, A.A. Physiological response of the three most cultivated pepper species (Capsicum spp.) in Africa to drought stress imposed at three stages of growth and development. Sci. Hortic. 2017, 224, 198-205. [CrossRef]

46. Jones, M.M.; Turner, N.C.; Osmond, C.B. Mechanisms of drought resistance. In The Physiology and Biochemistry of Drought Resistance in Plants; Paleg, L.G., Aspinal, D., Eds.; Academic Press: Sydney, Australia, 1981; pp. 15-35.

47. Chyliński, W.K.; Łukaszewska, A.J.; Kutnik, K. Drought response of two bedding plants. Acta Physiol. Plant. 2007, 29, 399-406. [CrossRef]

48. Heschel, M.S.; Sultan, S.E.; Glover, S.; Sloan, D. Population differentiation and plastic responses to drought stress in the generalist annual Polygonum persicaria. Int. J. Plant Sci. 2004, 165, 817-824. [CrossRef]

49. Azhar, N.; Hussain, B.; Ashraf, M.Y.; Abbasi, K.Y. Water stress mediated changes in growth: Physiology and secondary metabolites of desi ajwain (Trachyspermum ammi L.). Pak. J. Bot. 2011, 43, 15-19.

50. Khalid, K.A. Influence of water stress on growth essential oil and chemical composition of herbs (Ocimum sp.). Int. Agrophys. 2006, 20, 289-296.

51. Gao, S.; Wang, Y.; Yu, S.; Huang, Y.; Liu, H.; Chen, W.; He, X. Effects of drought stress on growth, physiology and secondary metabolites of two Adonis species in Northeast China. Sci. Hortic. 2020, 259, 108795. [CrossRef]

52. Borges, I.B.; Cardoso, B.K.; Silva, E.I.S.; de Oliveira, J.E.S.; da Silva, R.F.; de Rezende, C.A.M.; Gonçalves, J.E.; Junior, R.P.; de Souza, S.G.H.; Gazim, Z.C. Evaluation of performance and chemical composition of Petroselinum crispum essential oil under different conditions of water deficit. Afr. J. Agric. Res. 2016, 11, 480-486. [CrossRef]

53. Zulfiqar, F.; Younis, A.; Riaz, A.; Mansoor, F.; Hameed, M.; Akram, N.A.; Abideen, Z. Morpho-anatomical adaptations of two Tagetes erecta L. cultivars with contrasting response to drought stress. Pak. J. Bot. 2020, 52, 801-810. [CrossRef]

54. Sánchez-Blanco, M.J.; Álvarez, S.; Ortuño, M.F.; Ruiz-Sánchez, M.C. Root system response to drought and salinity: Root distribution and water transport. In Root Engineering; Soil Biology Series; Morte, A., Varma, A., Eds.; Springer: Berlin/Heidelberg, Germany, 2014; Volume 40, pp. 325-352. [CrossRef] 
55. Eziz, A.; Yan, Z.; Tian, D.; Han, W.; Tang, Z.; Fang, J. Drought effect on plant biomass allocation: A meta-analysis. Ecol. Evol. 2017, 7, 11002-11010. [CrossRef] [PubMed]

56. Toscano, S.; Scuderi, D.; Giuffrida, F.; Romano, D. Responses of Mediterranean ornamental shrubs to drought stress and recovery. Sci. Hortic. 2014, 178, 145-153. [CrossRef]

57. Toscano, S.; Ferrante, A.; Romano, D. Response of Mediterranean ornamental plants to drought stress. Horticulturae 2019, 5, 6. [CrossRef]

58. Flexas, J.; Medrano, H. Drought-inhibition of photosynthesis in C3 plants: Stomatal and non-stomatal limitations revisited. Ann. Bot. 2002, 89, 183-189. [CrossRef]

59. Drake, P.L.; Froend, R.H.; Franks, P.J. Smaller, faster stomata: Scaling of stomatal size, rate of response, and stomatal conductance. J. Exp. Bot. 2013, 64, 495-505. [CrossRef] [PubMed]

60. Soltys-Kalina, D.; Plich, J.; Strzelczyk-Żyta, D.; Śliwka, J.; Marczewski, W. The effect of drought stress on the leaf relative water content and tuber yield of a half-sib family of 'Katahdin'-derived potato cultivars. Breed. Sci. 2016, 66, 328-331. [CrossRef]

61. Babaei, K.; Moghaddam, M.; Farhadi, N.; Pirbalouti, A.G. Morphological, physiological and phytochemical responses of Mexican marigold (Tagetes minuta L.) to drought stress. Sci. Hortic. 2021, 284, 110116. [CrossRef]

62. Ueda, A.; Kanechi, M.; Uno, Y.; Inagaki, N. Photosynthetic limitations of a halophyte sea aster (Aster tripolium L.) under water stress and $\mathrm{NaCl}$ stress. J. Plant Res. 2003, 116, 63-68. [CrossRef] [PubMed]

63. Merwad, A.M.A.; Desoky, E.M.; Rady, M.M. Response of water deficit-stressed Vigna unguiculata performances to silicon, proline or methionine foliar application. Sci. Hortic. 2018, 228, 132-144. [CrossRef]

64. Jaleel, C.A.; Manivannan, P.; Lakshmanana, G.M.A.; Gomathinayagam, M.; Panneerselvam, R. Alterations in morphological parameters and photosynthetic pigment responses of Catharanthus roseus under soil water deficits. Colloids Surf. B Biointerfaces 2008, 61, 298-303. [CrossRef]

65. Kiani, S.P.; Maury, P.; Sarrafi, A.; Grieu, P. QTL analysis of chlorophyll fluorescence parameters in sunflower (Helianthus annuus L.) under well-watered and water stressed conditions. Plant. Sci. 2008, 175, 565-573. [CrossRef]

66. Asrar, A.W.A.; Elhindi, K.M. Alleviation of drought stress of marigold (Tagetes erecta) plants by using arbuscular mycorrhizal fungi. Saudi J. Biol. Sci. 2011, 18, 93-98. [CrossRef]

67. Oraee, A.; Tehranifar, A. Evaluating the potential drought tolerance of pansy through its physiological and biochemical responses to drought and recovery periods. Sci. Hortic. 2020, 265, 109225. [CrossRef]

68. Rosales-Serna, R.; Kohashi-Shibata, J.; Acosta-Gallegos, J.A.; Trejo-López, C.; Ortiz Cereceres, J.; Kelly, J.D. Biomass distribution, maturity acceleration and yield in drought stressed common bean cultivars. Field Crop. Res. 2004, 85, 203-211. [CrossRef]

69. Lu, F.; Bu, Z.; Lu, S. Estimating chlorophyll content of leafy green vegetables from adaxial and abaxial reflectance. Sensors 2019, 19, 4059. [CrossRef]

70. Abid, M.; Ali, S.; Qi, L.K.; Zahoor, R.; Tian, Z.; Jiang, D.; Snider, J.L.; Dai, T. Physiological and biochemical changes during drought and recovery periods at tillering and jointing stages in wheat (Triticum aestivum L.). Sci. Rep. 2018, 8, 4615-4630. [CrossRef] [PubMed]

71. Aghaie, P.; Tafreshi, S.A.H.; Ebrahimi, M.A.; Haerinasab, M. Tolerance evaluation and clustering of fourteen tomato cultivars grown under mild and severe drought conditions. Sci. Hortic. 2018, 232, 1-12. [CrossRef]

72. Oraee, A.; Tehranifar, A.; Nezami, A.; Shoor, M. Effects of drought stress on cold hardiness of non-acclimated viola (Viola $\times$ wittrockiana 'Iona Gold with Blotch') in controlled conditions. Sci. Hortic. 2018, 238, 98-106. [CrossRef]

73. Zegaoui, Z.; Planchais, S.; Cabassa, C.; Djebbar, R.; Belbachir, O.A.; Carol, P. Variation in relative water content, proline accumulation and stress gene expression in two cowpea landraces under drought. J. Plant. Physiol. 2017, 218, 26-34. [CrossRef]

74. Devi, M.A.; Giridhar, P. Variations in physiological response, lipid peroxidation, antioxidant enzyme activities, proline and isoflavones content in soybean varieties subjected to drought stress. Proc. Natl. Acad. Sci. USA 2015, 85, 35-44. [CrossRef]

75. Egert, M.; Tevini, M. Influence of drought on some physiological parameters symptomatic for oxidative stress in leaves of chives (Allium schoenoprasum). Environ. Expt. Bot. 2002, 48, 43-49. [CrossRef]

76. Gupta, D.K.; Palma, J.M.; Corpas, F.J. (Eds.) Redox State as a Central Regulator of Plant-Cell Stress Responses; Springer International Publishing: Berlin/Heidenberg, Germany, 2016; p. 386. [CrossRef]

77. Amiri, R.; Nikbakht, A.; Etemadi, N. Alleviation of drought stress on rose geranium [Pelargonium graveolens (L.) Herit.] in terms of antioxidant activity and secondary metabolites by mycorrhizal inoculation. Sci. Hortic. 2015, 197, 373-380. [CrossRef]

78. Tian, Z.; Wang, F.; Zhang, W.; Liu, C.; Zhao, X. Antioxidant mechanism and lipid peroxidation patterns in leaves and petals of marigold in response to drought stress. Hortic. Environ. Biotechnol. 2012, 53, 183-192. [CrossRef]

79. Seki, M.; Umezawa, T.; Urano, K.; Shinozaki, K. Regulatory metabolic networks in drought stress responses. Curr. Opin. Plant Biol. 2007, 10, 296-302. [CrossRef]

80. Chaeikar, S.S.; Marzvan, S.; Khiavi, S.J.; Rahimi, M. Changes in growth, biochemical, and chemical characteristics and alteration of the antioxidant defense system in the leaves of tea clones (Camellia sinensis L.) under drought stress. Sci. Hortic. 2020, $265,109257$. [CrossRef] 
81. Espinoza, A.; Martína, A.S.; Lopez-Climentb, M.; Ruiz-Laraa, S.; Gomez-Cadenasb, A.; Casarettoa, J. Engineered drought-induced biosynthesis of $\alpha$-tocopherol alleviates stress-induced leaf damage in tobacco. J. Plant Physiol. 2013, 170, 1285-1294. [CrossRef] [PubMed]

82. Catola, S.; Marino, G.; Emiliani, G.; Huseynova, T.; Musayev, M.; Akparov, Z.; Maserti, B.E. Physiological and metabolomic analysis of Punica granatum (L.) under drought stress. Planta 2016, 243, 441-449. [CrossRef] [PubMed] 